

\section{Race and the Yugoslav region}

\section{MANCHESTER 1824 \\ Manchester University Press}




\section{THEORY FOR A GLOBAL AGE}

Series Editor: Gurminder K. Bhambra, Professor of Postcolonial and Decolonial Studies in the School of Global Studies, University of Sussex

Globalization is widely viewed as a current condition of the world, but there is little engagement with how this changes the way we understand it. The Theory for a Global Age series addresses the impact of globalization on the social sciences and humanities. Each title will focus on a particular theoretical issue or topic of empirical controversy and debate, addressing theory in a more global and interconnected manner. With contributions from scholars across the globe, the series will explore different perspectives to examine globalization from a global viewpoint. True to its global character, the Theory for a Global Age series will be available for online access worldwide via Creative Commons licensing, aiming to stimulate wide debate within academia and beyond.

\section{Previously published by Bloomsbury:}

Connected Sociologies

Gurminder K. Bhambra

Eurafrica: The Untold History of European Integration and Colonialism

Peo Hansen and Stefan Jonsson

On Sovereignty and Other Political Delusions

Joan Cocks

Postcolonial Piracy: Media Distribution and Cultural Production in the Global South

Edited by Lars Eckstein and Anja Schwarz

The Black Pacific: Anti-Colonial Struggles and Oceanic Connections

Robbie Shilliam

Democracy and Revolutionary Politics Neera Chandhoke

\section{Published by Manchester University} Press:

\section{Debt as Power}

Tim Di Muzio and Richard H. Robbins

Subjects of modernity: Time-space, disciplines, margins Saurabh Dube

\section{Frontiers of the Caribbean} Phillip Nanton

John Dewey: The Global Public and Its Problems

John Narayan 


\title{
Race and the Yugoslav region
}

\author{
Postsocialist, post-conflict, \\ postcolonial?
}

Catherine Baker

Manchester University Press 
Copyright (C) Catherine Baker 2018

The right of Catherine Baker to be identified as the author of this work has been asserted by her in accordance with the Copyright, Designs and Patents Act 1988.

Published by Manchester University Press

Altrincham Street, Manchester M1 7JA

www.manchesteruniversitypress.co.uk

British Library Cataloguing-in-Publication Data

A catalogue record for this book is available from the British Library

Library of Congress Cataloging-in-Publication Data applied for

ISBN 9781526126603 hardback

ISBN 9781526126627 paperback

ISBN 9781526126610 open access

This electronic version has been made freely available under a Creative Commons (CC-BY-NC-ND) licence. A copy of the licence can be viewed at https://creativecommons.org/licenses/by-nc-nd/3.0/

First published 2018

The publisher has no responsibility for the persistence or accuracy of URLs for any external or third-party internet websites referred to in this book, and does not guarantee that any content on such websites is, or will remain, accurate or appropriate. 